\title{
9. Exile as a Loss of Identity: Saul Friedländer
}

An entirely new chapter in the character of exile starts with WWII, as reality became almost unrecognizable for Europeans, and for Jews especially. We can speak here of a loss of identity on a global scale through utter abandonment, anguish, defenselessness, and dehumanization, which take many important forms that, however, have one thing in common - a loss of faith leading to the hardening of the human heart.

The issue of the loss of identity is brilliantly exemplified in the work of the historian Saul Friedländer (born 1932 in Prague). Friedländer grew up in France and survived the occupation as a child in a Catholic boarding school near Vichy (1942-1944), while his parents were arrested by Vichy French gendarmes, turned over to the Germans, and gassed at Auschwitz. He got to know about the death of his parents and about his Jewish provenience only in 1946. He became a Zionist and emigrated to Israel in 1948. He then studied political science in Paris in the fifties and became an assistant to Shimon Peres, then vice-minister of defense of Israel. He received a Ph.D. in Geneva in 1963 and taught there until 1988, when he became a professor of history at the University of California, Los Angeles. He received many major prizes for his books on the history of Jews in the twentieth century.

In his books Nazi Germany and the Jews: The Years of Persecution, 1933-1939 and The Years of Extermination: Nazi Germany and the Jews, 1939-1945 (winner of the 2008 Pulitzer Prize for Nonfiction), Friedländer drew from newly available documents-such as local German police reports, films, personal recollections, as well as from his own experiences-producing an intimate picture of prewar Germany as grotesque and chilling under the veneer of an even 
more chilling normality. Most strikingly, Friedländer concludes that the largely middle-class, educated population of one of the world's most advanced nations "looked the other way" during the systematic removal of Jews from Germany's government, business, and cultural life in the pre-Holocaust years. In short, they viewed Hitler's anti-Jewish actions during a time of economic prosperity and growing international power as a "peripheral issue."

Friedländer documents how one anti-Jewish measure took place after another and the fate of each individual Jewish community in Europe. Thus, for example, in April 1933 alone, the Nazis declared a boycott of Jewish businesses, passed a law requiring nonAryan civil servants to retire, and limited the number of Jewish students eligible to attend German universities. They compelled some two million state employees and tens of thousands of lawyers, doctors, students, and others to search for proof of Aryan ancestry and transformed tens of thousands of priests, pastors, town clerks, and archivists into investigators to vouch for blood purity.

According to Friedländer, Hitler's main goal in the late thirties was to force Jewish emigration by confiscating Jewish wealth, forcing Jews by law to sell their businesses, land, stocks, jewels, and artworks, thereby entirely destroying "any remaining possibility for Jewish life in Germany." Looting Jewish property on this scale was a substantial element of the twelve years of the Third Reich. Later, all the property of evacuated and murdered Jews was seized. Friedländer finds, however, no evidence of any plan for extermination prior to Germany's invasion of the Soviet Union. In all those years,

not one social group, not one religious community, not one scholarly institution or professional association in Germany and throughout Europe declared its solidarity with the Jews... ; to the contrary, many social constituencies, many power groups were directly involved in the expropriation of Jews and anxious, be it out of greed, for their wholesale disappearance. Thus Nazi and 
anti-Jewish policies could unfold to their most extreme levels without the interference of any major countervailing interests. ${ }^{36}$

Friedländer collected layers of detail from the otherwise unremembered lives of people who ended up as corpses piled into the death pits. He is a world authority on the Shoah, as well as a survivor. "The goal of [conventional] historical knowledge," he writes, "is to domesticate disbelief." He states, instead, that disbelief is the only morally coherent starting point for thinking about what happened, a visceral response that should never be domesticated. He believes that the mass killings of Jews in the East-which were initially thought of simply as by-products of "the war of extermination and the destruction of 'Judeo-Bolshevism,"' were no different from the industrial genocide that followed. Friedländer's real purpose is not to lay bare the administrative machinery of the Holocaust, but to expose the failure of nerve at every level, and the profound unwillingness to confront it.

The Nazi state first achieved the isolation of millions of Jews from their neighbors through the ever-increasing weight of official vindictiveness. Jews were gradually restricted in their shopping hours, their schools, and their use of titles, telephones, cars, bicycles, and electrical appliances; they had to build their own air raid shelters, use their own cobblers, were denied fruit, gingerbread, chocolate, white bread, furs, and tobacco, and finally pets (which they couldn't even pass over to a neighbor, but were ordered to murder). Even so, when, in the East, the extermination began operating, Jews in the West could still live restricted lives for a while without a sense of immediate danger amid neighbors who, on a personal level, were sometimes sympathetic if unengaged. Friedländer's book stresses the collective timidity of so many with whom the reader can uncomfortably identify. Ordinary people may have been distressed by what they saw, but in the face of the state's

36 Saul Friedländer, Nazi Germany and the Jews: The Years of Persecution, 1933-1939 (New York: HarperCollins Publishers, 1997) and The Years of Extermination: Nazi Germany and the Jews, 1939-1945 (New York: HarperCollins Publishers, 2007), xxi. 
brutality and the success of its propaganda machine, they feared first for themselves.

According to Friedländer, while Hitler's personal obsession was the root cause of the Shoah, the course it took was only possible because of endemic European antisemitism. Friedländer charts chronologically the progress from administrative cruelties to the industrial mass murder of Auschwitz. His work helps explain the paralysis of Jews who were unable to accept what was happening until it was too late to escape and also how difficult it was for others to decide at what point to risk their own safety by taking a stand. Everyone went through a growing sense of disbelieving recognition. The few survivors lived subsequently in the shadow of the six million murdered. Some Jews were issued exemption stamps by the Nazis, but this only allowed people to save themselves at the expense of others and served to divide and demoralize the Jews via the institutions of Jewish council. Camp survivors were simply not believed.

Some occupied countries have better records about attempts to save Jews from the Nazi murderers than others. Belgium, Finland, Romania, Italy, Denmark, Bulgaria, and Hungary tried their best to stall or even obstruct deportations, while France, Switzerland, and Poland have particularly abominable records (not to mention Ukraine, Lithuania, and those other East European countries which actively participated in the murders). But even more distant countries famously returned ships with Jewish refugees back to Germany or Poland (Great Britain and the US, primarily). By the end of 1942, every nation knew - East and West - that the Jews were destined for complete extermination. Knowledge about the conditions and mass murders in concentration camps was also public by that time. The Vatican knew about it by early 1942. The pope did nothing and did not condemn the atrocities. ${ }^{37}$ Europe turned from a home into the origin of a great exodus - there was no sense in staying anymore, even if one could save oneself. The Jews deported to concentration camps were subjected to inhuman treatment and humiliation,

37 Ibid., xxiii. Friedländer complains that the Vatican archives are still inaccessible to historians, as of writing this book. 
which aimed at destroying their identities as human beings. Such extreme loss not only haunted survivors for the rest of their lives, but will also haunt future generations.

Friedländer's brilliant book of memoirs and essays When Memory Comes was published in 1978 in the US. It depicts another extreme form of exile as a personal loss of identity. Not only was he, as a young boy, forced to go through a sad separation from his parents, but he gradually lost a sense of who he was. This was forced upon him by the necessity to survive. He writes that he was denied his heritage and reality. In order to save his life, his parents kept his identity hidden from him and managed to place him in a Catholic boarding school. There, he became a devoted Catholic, living in a protected environment throughout the war, never knowing what was really going on, what had happened to his parents, or who he actually was.

When the war was over, a priest revealed the truth to him and a gradual awakening began. He was originally called Pavlíček, but to hide his Jewish associations his name was changed to Paul. After the war, he changed his name to Shaul and moved to Israel. The memoir is written in flashbacks to his former life in Prague and France. Thus, Pavlíček became Paul-Henri Ferland, then Shaul, and finally Saul. The book also shows how difficult it was for this assimilated and secular Jew to identify with the Jewish race. His Jewishness was purely negative, formed only from the outside and based on identification with his fellow sufferers. Being brought up Catholic, he had even taken on a subtle antisemitism. When offered to live with his grandmother in Sweden, he refused in order to continue his Catholic studies (he was planning to become a priest at that point). For a while, he lived with a Russian Polish Orthodox guardian. This gripping story of gradual awakening has become well known in the US, but still remains obscure in Friedländer's native land.

Friedländer's autobiographical story of loss of personal and national identity is a metaphor for a broader and systematic loss of identity imposed on the Jews by the events of the twentieth century in Europe - the gradual closing off of human living space, which became progressively hostile and unlivable. 